\title{
Anticancer Activity of Metal Complexes with Acesulfame Mixed with Triphenylphosphine Ligands
}

\author{
Bussaba Boonseng*, Teerawat Khudkham, \\ Sutthida Wongsuwan, and Jaruwan Chatwichien
}

Faculty of Science, Naresuan University, Phitsanulok 65000, Thailand

*Corresponding author.E-mail: bussabab@nu.ac.th

https://doi.org/10.12982/CMUJNS.2019.0029

Received: November 6, 2018

Revised: March 1, 2019

Accepted: March 18, 2019

\begin{abstract}
Metal complexes of silver(I), nickel(II) and copper(II) with the mixed ligands of acesulfame (ace) and triphenylphosphine $\left(\mathrm{PPh}_{3}\right)$ were prepared in this work. The complexes of $[\mathrm{Ag}(\mathrm{ace})]_{n}(1),\left[\mathrm{Ag}(\mathrm{ace})\left(\mathrm{PPh}_{3}\right]\right.$ ] (2), $\left[\mathrm{Ni}(\mathrm{ace})_{2}\left(\mathrm{H}_{2} \mathrm{O}\right)_{4}\right] \quad(3),\left[\mathrm{Ni}(\mathrm{ace})_{2}\left(\mathrm{PPh}_{3}\right)_{2}\right] \quad(4), \quad\left[\mathrm{Cu}(\mathrm{ace})_{2}\left(\mathrm{H}_{2} \mathrm{O}\right)_{2}\right] \quad$ (5) and ICu(ace $)_{2}\left(\mathrm{PPh}_{3}\right)_{2}$ (6) were characterised by FT-IR and NMR spectroscopy, Mass spectrometry including X-Ray powder diffraction. The synthesised complexes were examined in their anticancer activity against A549 lung cancer cells which were further evaluated their efficiency by $I C_{50}$ method. [Ag(ace) $]_{n}(1)$, [Ni(ace $\left.)_{2}\left(\mathrm{H}_{2} \mathrm{O}\right)_{4}\right]$ (3) and $\left[\mathrm{Cu}(\mathrm{ace})_{2}\left(\mathrm{H}_{2} \mathrm{O}\right)_{2}\right]$ (5) which contain only acesulfame ligand exhibited higher $I C_{50}$ values in comparison to the mixed ligands of ace and $\mathrm{PPh}_{3^{*}}\left[\mathrm{Ag}(\right.$ ace $\left.)\left(\mathrm{PPh}_{3}\right)\right](2)$, [Ni(ace $\left.)_{2}\left(\mathrm{PPh}_{3}\right)_{2}\right]$ (4) and $\left[\mathrm{Cu}(\mathrm{ace})_{2}\left(\mathrm{PPh}_{3}\right)_{2} \mathrm{I}(6)\right.$ displayed the inhibition in the growth of cancer cells with $I C_{50}$ values of $1.65,13.45$ and $1.06 \mu M$, respectively. Additionally, silver(I) and copper(II) complexes also presented better activity than the standard Etoposide $\left(I C_{50} 5.623 \mu M\right)$. The results indicated that the mixed ligands could perform more excellent inhibition of cancer cells growing in comparison to the using of only acesulfame or triphenylphosphine ligand.
\end{abstract}

Keywords: Complexes, Acesulfame, Anticancer, Triphenylphosphine 


\section{INTRODUCTION}

Anticancer activity is one of the most attractive applications involved the examination in capability of coordination compounds in biological studies. Silver(I) complexes was found to be the most effective substrate in antibacterial and antifungal studies for several years (Kumar et al.,2010; Chandra and Ruchi, 2013; Charef et al., 2015. Our recent research also revealed that silver(I) complexes incorporated with the mixed ligands of triphenylphosphine and acesulfame exhibit excellent activity against A549 lung cancer cells (Boonseng et al., 2018). Herein, we would like to expand the scope of metals to the first-row transition metals; nickel(II) and copper(II) which has been prevalently used for numerous catalysis and biological studies (Chandra et al., 2015; Ghobadi et al., 2018; Mo et al., 2018; Saha et al., 2018).

Acesulfame- $\mathrm{K}$ is a commercially artificial sweetener in which its anionic form is considered to be an excellent ligand according to the containing of several donor atoms. Apart from conveniently and commercially available, the compound was also found to provide low toxicity at low concentration leading to the practically using for living organism (Cong et al., 2013). Owing to the prior advantage of acesulfame-K, the recent research by Cavicchioli and co-workers (2010) was revealed that the using of acesulfame as the ligand for platinum(II) and silver(I) complexes exhibited exceptional antimycobacterial and antibacterial activity. Moreover, in order to improve the ability of metal complexes in biological activities regarding the inhibition of cancer cells growing, several researches have been attracted to the structural modification of transition metal complexes. The study by the Nawaz group (2011) revealed that the introduction of triphenylphosphine $\left(\mathrm{PPh}_{3}\right)$ into the heterocyclic thiones silver(I) complexes could perform more excellent activity against cancer cells than using only thione compounds. Thereafter, Kaplan and co-workers reported the activity of silver(I) complex against lung cancer A549 cells via MTT assay in which the better reactivity of such complex than its coordinated ligands were discovered (Kaplan, 2017). Lung cancer has become our desired target according to the report by World Health Organization (WHO) which indicated that lung cancer is the most common cause of cancer-related death of people and more than 50 percent of lung cancer cases occurred in less developed countries (Gazdar et al., 2010).

Therefore, in this study, the complexes of silver(I), nickel(II) and copper(II) incorporated with the mixed ligands of acesulfame and $\mathrm{PPh}_{3}$ were synthesized and their structures were determined by FT-IR, ${ }^{1} \mathrm{H}$ and ${ }^{31} \mathrm{P}$ NMR spectroscopy, mass spectrometry including X-Ray powder diffraction. The products were examined in their inhibition of lung cancer cells growing (A549) and their abilities were presented and compared in term of $\mathrm{IC}_{50}$ values. 


\section{MATERIALS AND METHODS}

\section{Materials}

All the chemicals used in this study were at least analytical grade. Silver nitrate $\left(\mathrm{AgNO}_{3}\right)$ was obtained from Labscan. $\mathrm{NiCl}_{2}\left(\mathrm{PPh}_{3}\right)_{2}, \mathrm{Ni}\left(\mathrm{CH}_{3} \mathrm{CO}_{2}\right)_{2} \cdot 4 \mathrm{H}_{2} \mathrm{O}$ and $\mathrm{Cu}\left(\mathrm{CH}_{3} \mathrm{CO}_{2}\right)_{2} \cdot \mathrm{xH}_{2} \mathrm{O}$ were purchased from Aldrich. Triphenylphosphine $\left(\mathrm{PPh}_{3}\right)$ and acesulfame-K (ace-K) were supplied by Fluka. Other solvents were used without further purification. The IR spectra were recorded in wavenumber region 4,000-400 $\mathrm{cm}^{-1}$ on a PerkinElmer FT-IR spectrophotometer. The ${ }^{1} \mathrm{H}$ and ${ }^{31} \mathrm{P}$ NMR spectra in DMSO- $d_{6}$ were operated at the frequency of $400 \mathrm{MHz}$ (Bruker). Mass spectrometric analysis was performed using the ESI technique (Agilent 6540 LC/MS system). X-Ray powder diffraction was performed using diffractometer provided by Rigaku (MiniflexII). [3-(4,5-dimethylthiazol2-yl)-2,5-diphenyltetrazolium bromide] (MTT) assay was analysed by measurement the absorbance of formarzan product using Microplate Reader from PerkinElmer, Spectrum GX.

\section{Synthesis of metal complexes with acesulfame and mixed ligands of acesulfame and triphenylphosphine}

Silver(I) complexes. $[\operatorname{Ag}(\text { ace })]_{n}(1)$ was prepared according to the literature (Cavicchioli et al., 2010). $2.0 \mathrm{mmol}$ of $\mathrm{AgNO}_{3}$ was dissolved in water $25 \mathrm{~mL}$ and was then slowly added to the aqueous solution of acesulfame-K $(2.0 \mathrm{mmol}, 25 \mathrm{~mL})$ under stirring. The mixture solution was left in the absence of light for slow evaporation for 2 days and the colorless crystals were obtained. $\left[\mathrm{Ag}(\mathrm{ace})\left(\mathrm{PPh}_{3}\right)\right]$ (2) was synthesized by the addition of $\mathrm{AgNO}_{3}(1.0 \mathrm{mmol})$ aqueous solution into the ethanolic solution of $\mathrm{PPh}_{3}(1.0 \mathrm{mmol})$. After stirring at $80{ }^{\circ} \mathrm{C}$ for 2 hours, acesulfame-K $(1.0 \mathrm{mmol})$ in water was added into the mixture with continuously stirring at room temperature for 5 hours. The obtained product was filtered and recrystallized with ethanol.

Nickel(II) complexes. [ $\left.\mathrm{Ni}(\text { ace })_{2}\left(\mathrm{H}_{2} \mathrm{O}\right)_{4}\right](3)$ was prepared according to the literature (Icbudak et al., 2006) by adding drop-wise of an aqueous solution of acesulfame-K $(2.0 \mathrm{mmol}) 50 \mathrm{~mL}$ into a hot solution of $\mathrm{Ni}\left(\mathrm{CH}_{3} \mathrm{CO}_{2}\right)_{2} \cdot 4 \mathrm{H}_{2} \mathrm{O}$ $(1.0 \mathrm{mmol})$ in $50 \mathrm{ml}$ ethanol with continuously stirring. The mixture was stirred at $80{ }^{\circ} \mathrm{C}$ for 2 hours. The green powder was achieved after the evaporation of solvent. [Ni(ace $)_{2}\left(\mathrm{PPh}_{3}\right)_{2}$ ] (4) was synthesized by adding the ethanolic solution of acesulfame-K $(2.0 \mathrm{mmol})$ into the round bottom flask containing $\mathrm{NiCl}_{2}\left(\mathrm{PPh}_{3}\right)_{3}(1.0 \mathrm{mmol})$ in ethanol. The mixture was kept under reflux for 3 hours, then the reaction was cooled down to room temperature. The desired product was obtained by filtration and the filtrate was removed its solvent by rotary evaporator, the pale-green solid was yielded. 
Copper(II) complexes. $\left[\mathrm{Cu}(\text { ace })_{2}\left(\mathrm{H}_{2} \mathrm{O}\right)_{2}\right]$ (5) was synthesized with the same procedure as complex $\left[\mathrm{Ni}(\text { ace })_{2}\left(\mathrm{H}_{2} \mathrm{O}\right)_{4}\right]$ (3) using $\mathrm{Cu}\left(\mathrm{CH}_{3} \mathrm{CO}_{2}\right)_{2} \cdot \mathrm{xH}_{2} \mathrm{O}$ instead of $\mathrm{Ni}\left(\mathrm{CH}_{3} \mathrm{CO}_{2}\right)_{2} \cdot 4 \mathrm{H}_{2} \mathrm{O}$. The product was obtained as pale-blue solid. $\left[\mathrm{Cu}(\mathrm{ace})_{2}\left(\mathrm{PPh}_{3}\right)_{2}\right]$ (6) was prepared by mixing $\mathrm{Cu}\left(\mathrm{CH}_{3} \mathrm{CO}_{2}\right)_{2} \mathrm{xH}_{2} \mathrm{O}$ and two equivalents of acesulfame- $\mathrm{K}$ and $\mathrm{PPh}_{3}$. The reaction was set up in the same condition as for complex $\left[\mathrm{Ag}(\mathrm{ace})\left(\mathrm{PPh}_{3}\right)\right](2)$ to yield blue solid of the product.

\section{Anticancer studies}

The anticancer activity of the synthesized complexes was investigated against A549 lung cancer cells and further evaluated by $\mathrm{IC}_{50}$ method. A549 cells (about 5,000 cells/well) were incubated in complete medium ( $10 \%$ fetal bovine serum $+1 \%$ Penicillin Streptomycin in modified Eagle's medium) at $37{ }^{\circ} \mathrm{C}$ for 8 hours. The synthesized complexes were dissolved in water or dimethylsulfoxide with concentration of $50 \mathrm{mM}$ and then a series of diluted solutions was added in triplicate into each well. The cells were incubated at $37^{\circ} \mathrm{C}$ for 48 hours and after that the added media were aspirated. The MTT reagent $(1 \%$ in growth media) $100 \mu \mathrm{L}$ was added to each well and incubated at $37{ }^{\circ} \mathrm{C}$ for 4 hours. After the removal of MTT solution, $100 \mu \mathrm{L}$ of dimethylsulfoxide was added to observe the absorbance at $\lambda_{\max }=570 \mathrm{~nm}$. The results were calculated for $\mathrm{IC}_{50}$ values using GraphPad Prism7 software and compared with standard Etoposide.

\section{RESULTS}

Synthesis of metal complexes with acesulfame and mixed ligands of acesulfame and triphenylphosphine

The complexes of silver(I), nickel(II) and copper(II) were prepared as aforementioned in material and methods section. Melting points of complexes were determined at the heating rate of $5^{\circ} \mathrm{C} / \mathrm{min}$ using GALLENKAMP Melting Point Apparatus. Appearance and percentage yield of each compound are shown in Table 1. 
Table 1. General information of the synthesized complexes.

\begin{tabular}{llcc}
\hline \multicolumn{1}{c}{ Compounds } & \multicolumn{1}{c}{ Appearance } & \%Yield & Melting point $\left({ }^{\circ} \mathbf{C}\right)$ \\
\hline$[\mathrm{Ag}(\text { ace })]_{\mathrm{n}}(\mathbf{1})$ & White powder & 46.3 & 202.3 \\
{$\left[\mathrm{Ag}(\right.$ ace $\left.)\left(\mathrm{PPh}_{3}\right)\right](\mathbf{2})$} & White powder & 62.7 & 190.3 \\
{$\left[\mathrm{Ni}(\text { ace })_{2}\left(\mathrm{H}_{2} \mathrm{O}\right)_{4}\right](\mathbf{3})$} & Green powder & 72.0 & 94.3 \\
{$\left[\mathrm{Ni}(\text { ace })_{2}\left(\mathrm{PPh}_{3}\right)_{2}\right](\mathbf{4})$} & Green powder & 42.1 & 90.8 \\
{$\left[\mathrm{Cu}(\text { ace })_{2}\left(\mathrm{H}_{2} \mathrm{O}\right)_{2}\right](\mathbf{5})$} & Pale-blue powder & 50.8 & 262.2 \\
{$\left[\mathrm{Cu}(\text { ace })_{2}\left(\mathrm{PPh}_{3}\right)_{2}\right](6)$} & Blue powder & 36.3 & 217.7 \\
\hline
\end{tabular}

\section{Characterization of metal complexes with acesulfame and mixed ligands of acesulfame and triphenylphosphine}

The obtained complexes were analyzed in compositions and structures by IR and NMR spectroscopic methods, mass spectrometry including X-Ray powder diffraction to acquire molecular structures of the synthesized products.

\section{IR studies}

Acesulfame-K ligand displays frequencies at wavenumbers of 1,651, 1,588 and $1,287 \mathrm{~cm}^{-1}$ which are corresponding to the vibration of $\mathrm{C}=\mathrm{O}, \mathrm{S}(=\mathrm{O})_{2}$ and $\mathrm{C}-\mathrm{N}$ functional groups, respectively. The frequency changes upon the complex formation of copper(II) ion are presented as the spectra shown in Figure 1. The wavenumbers at $3,565 \mathrm{~cm}^{-1}$ and $3,431 \mathrm{~cm}^{-1}$ of $\left[\mathrm{Cu}(\text { ace })_{2}\left(\mathrm{H}_{2} \mathrm{O}\right)_{2}\right](5)$ are represented the stretching vibrations of $\mathrm{O}-\mathrm{H}$ functional group of water molecules and these vibrations are also displayed in $\left[\mathrm{Ni}(\text { ace })_{2}\left(\mathrm{H}_{2} \mathrm{O}\right)_{4}\right](3)$. Additionally, the carbonyl; $\mathrm{C}=\mathrm{O}$, and the sulfone; $\mathrm{S}(=\mathrm{O})_{2}$ groups of complex 5 also exhibit frequencies at lower wavenumbers, 1,646 and 1,580 $\mathrm{cm}^{-1}$, in comparison to the free acesulfame compound. Sharp bands are observed at wavenumbers of 527 and $516 \mathrm{~cm}^{-1}$ in complex 5 and wavenumbers of 518 and $644 \mathrm{~cm}^{-1}$ in complex 6 . The first peak in both complexes are assigned to the bond formation of copper(II) and nitrogen donor of acesulfame compound. The second peak of complex 5 shows the donation of water molecule towards the metal center whilst the assigned wavenumber of complex 6 belongs to M-P bond. 


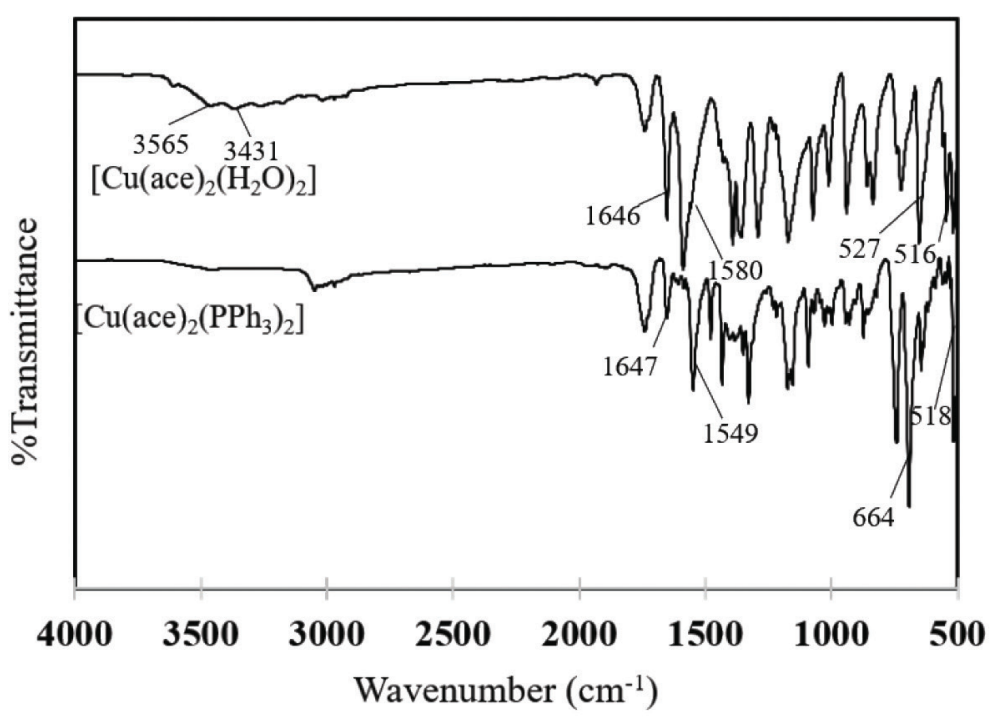

Figure 1. IR spectra of $\left[\mathrm{Cu}(\text { ace })_{2}\left(\mathrm{H}_{2} \mathrm{O}\right)_{2}\right](5)$ and $\left[\mathrm{Cu}(\text { ace })_{2}\left(\mathrm{PPh}_{3}\right)_{2}\right](6)$.

In order to compare the different types of metal centers affected the vibration frequencies, complexes 2, 4 and 6 are chosen and their spectra are presented in Figure 2. A high frequency shift in $v(\mathrm{C}-\mathrm{N})$ bands in all complexes indicate the coordination of ligand to the metal ions. M-N bond was observed in the region of 559-516 $\mathrm{cm}^{-1}$ whilst $\mathrm{M}-\mathrm{O}$ bond was also observed according to the metal-oxygen of water or metal-oxygen of acesulfame molecule. Moreover, the frequencies involved M-P bond formation in complexes 2, 4 and 6 were exhibited at the wavenumbers about $660-640 \mathrm{~cm}^{-1}$. In addition, an unexpected signal was observed in complex 4 at the frequencies range of $3,400-3,050 \mathrm{~cm}^{-1}$ which might be attributed to the moisture contained in the substrate. IR data of free acesulfame ligand and all complexes are shown in Table 2.

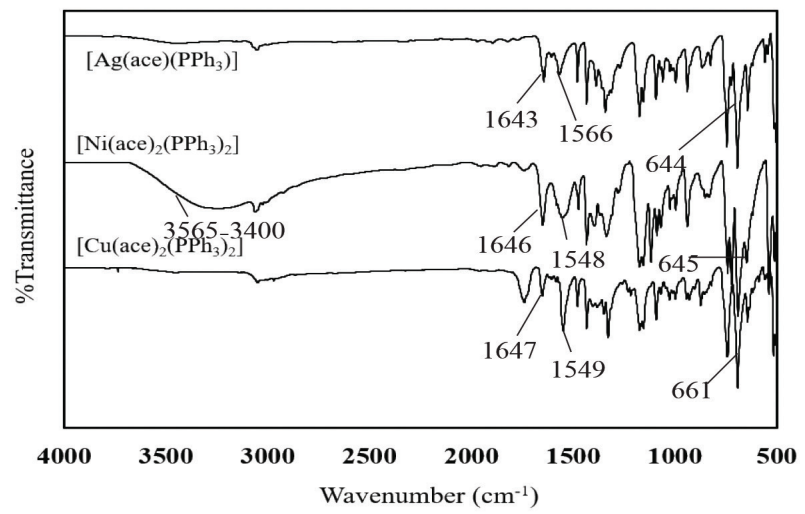

Figure 2. IR spectra of $\left[\mathrm{Ag}(\right.$ ace $\left.)\left(\mathrm{PPh}_{3}\right)\right](2),\left[\mathrm{Ni}(\text { ace })_{2}\left(\mathrm{PPh}_{3}\right)_{2}\right]$ (4) and $\left[\mathrm{Cu}(\text { ace })_{2}\left(\mathrm{PPh}_{3}\right)_{2}\right](6)$. 
Table 2. IR data of free ligands and complexes 1-6.

\begin{tabular}{|c|c|c|c|c|c|c|}
\hline Compounds & $\mathbf{v}(\mathrm{OH})$ & $\mathbf{v}(\mathrm{C}=\mathrm{O})$ & $v\left(S(=O)_{2}\right)$ & $v(\mathrm{C}-\mathrm{N})$ & $v(M-N)$ & $v(\mathbf{M}-\mathrm{O}) /(\mathrm{M} / \mathrm{P})$ \\
\hline Acesulfame & - & 1,651 & 1,588 & 1,287 & - & - \\
\hline$[\mathrm{Ag}(\text { ace })]_{\mathrm{n}}$ & - & 1,644 & 1,563 & 1,312 & 559 & $513(\mathrm{M}-\mathrm{O})$ \\
\hline$\left[\mathrm{Ag}(\right.$ ace $\left.)\left(\mathrm{PPh}_{3}\right)\right](\mathbf{2})$ & - & 1,643 & 1,566 & 1,342 & 557 & 644 (M-P) \\
\hline$\left[\mathrm{Ni}(\text { ace })_{2}\left(\mathrm{H}_{2} \mathrm{O}\right)_{4}\right](\mathbf{3})$ & $\begin{array}{l}3,465 \\
3,364\end{array}$ & 1,638 & 1,557 & 1,323 & 530 & $517(\mathrm{M}-\mathrm{O})$ \\
\hline$\left[\mathrm{Ni}(\text { ace })_{2}\left(\mathrm{PPh}_{3}\right)_{2}\right](4)$ & $\begin{array}{l}3,400- \\
3,050\end{array}$ & 1,644 & 1,548 & 1,334 & 538 & 645 (M-P) \\
\hline$\left[\mathrm{Cu}(\text { ace })_{2}\left(\mathrm{H}_{2} \mathrm{O}\right)_{2}\right](\mathbf{5})$ & $\begin{array}{l}3,565 \\
3,431\end{array}$ & 1,646 & 1,580 & 1,291 & 527 & $516(\mathrm{M}-\mathrm{O})$ \\
\hline$\left[\mathrm{Cu}(\text { ace })_{2}\left(\mathrm{PPh}_{3}\right)_{2}\right](6)$ & - & 1,647 & 1,549 & 1,329 & 518 & 664 (M-P) \\
\hline
\end{tabular}

\section{NMR studies}

The synthesized complexes were observed in ${ }^{1} \mathrm{H}$ and ${ }^{31} \mathrm{P}$ NMR spectra to examine the change of proton and phosphorus signals upon the coordination of ligands to the metal ions.

Generally, free $\mathrm{PPh}_{3}$ shows the ${ }^{31} \mathrm{P}$ signal at the chemical shift about $-5.25 \mathrm{ppm}$. For the synthesized complexes $\mathbf{2}, \mathbf{4}$ and $\mathbf{6}$, the observed phosphorus atom of each one was found to resonate at the chemical shift of 15.81, 25.62 and $25.50 \mathrm{ppm}$, respectively. Complex 2 has been already known in its molecular structure from X-ray single crystal diffraction previously reported by our group. Structure of $\left[\mathrm{Ag}(\mathrm{ace})\left(\mathrm{PPh}_{3}\right)\right](2)$ is shown in Figure 3.

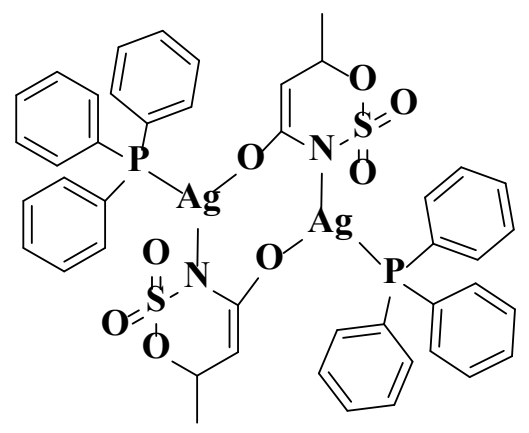

Figure 3. The molecular structure of $\left[\mathrm{Ag}(\mathrm{ace})\left(\mathrm{PPh}_{3}\right)\right](2)$. 
However, complexes $\mathbf{4}$ and $\mathbf{6}$ still cannot be affirmed the exact position of $\mathrm{PPh}_{3}$ coordinated to nickel(II) and copper(II) ions. To the extent of our knowledge including the steric bulk of $\mathrm{PPh}_{3}$, the proposed structures of the two complexes are presented in Figure 4. Moreover, the spectra also present the ${ }^{31} \mathrm{P}$ NMR signals at $-5.18 \mathrm{ppm}$ for complex 4 and $-5.05 \mathrm{ppm}$ for complex $\mathbf{6}$ which are attributed to the presence of unreacted $\mathrm{PPh}_{3}$. Such the peak was not observed in complex 2 according to the purified single crystal collected for the analysis by ${ }^{31} \mathrm{P}$ NMR spectroscopic technique. The ${ }^{31} \mathrm{P}$ spectra of complexes $\mathbf{2 , 4}$ and $\mathbf{6}$ are presented in Figure 5.

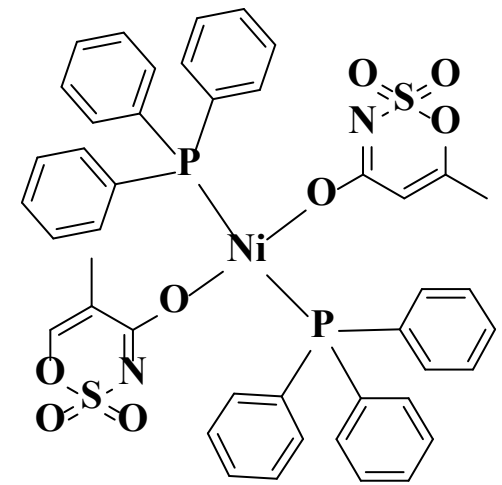

(a)

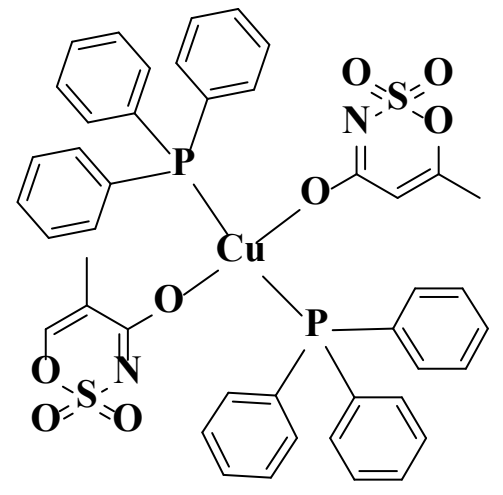

(b)

Figure 4. The proposed structures of (a) $\left[\mathrm{Ni}(\mathrm{ace})_{2}\left(\mathrm{PPh}_{3}\right)_{2}\right]$ (4) and (b) $\left[\mathrm{Cu}(\mathrm{ace})_{2}\left(\mathrm{PPh}_{3}\right)_{2}\right](6)$.

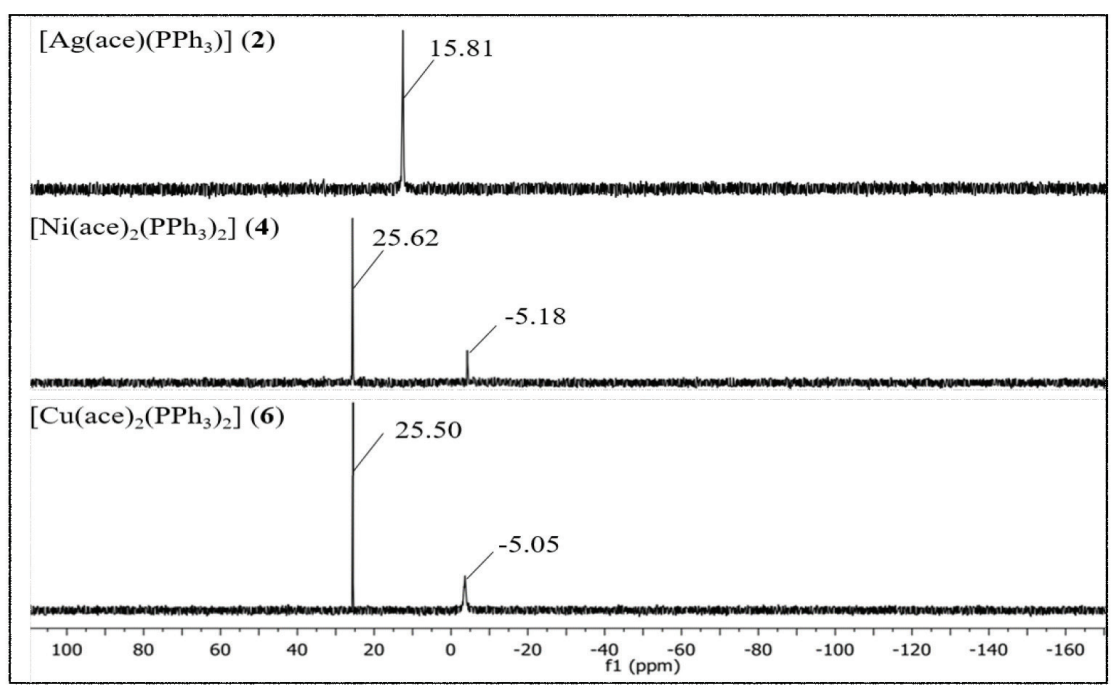

Figure 5. ${ }^{31} \mathrm{P}$ spectra of $\left[\mathrm{Ag}(\right.$ ace $\left.)\left(\mathrm{PPh}_{3}\right)\right](2),\left[\mathrm{Ni}(\text { ace })_{2}\left(\mathrm{PPh}_{3}\right)_{2}\right](4)$ and $\left[\mathrm{Cu}(\text { ace })_{2}\left(\mathrm{PPh}_{3}\right)_{2}\right](6)$. 
The orientation of $\mathrm{PPh}_{3}$ on the nickel(II) and copper(II) metal centers is supposed to be similar according to the comparable in their chemical shifts. Moreover, these values are also different from silver(I) complex in which the structure is in a dimer fashion with trigonal planar around the metal center (Figure 3). Unfortunately, for ${ }^{1} \mathrm{H}$ NMR study, the spectra could not be obtained to verify the complex formation as the signals of protons in acesulfame are all obscured by abundant protons of phenyl rings in $\mathrm{PPh}_{3}$. For the complexes contained only acesulfame ligand; complexes 1, 3 and 5, ${ }^{1} \mathrm{H}$ NMR study could be constructed. The ${ }^{1} \mathrm{H}$ spectra of the novel complex $\mathbf{5}$ revealed the signals at the chemical shifts of 5.26 and $1.89 \mathrm{ppm}$ belonged to the proton at para position of sulfone functional group $\left(\mathrm{H}_{\mathrm{A}}\right)$ and the protons of methyl substituent $\left(\mathrm{H}_{\mathrm{B}}\right)$ with the integration ratio of 1:3 (Figure 6). These peaks exhibited upfield shifted from 6.04 and $2.20 \mathrm{ppm}$ in free acesulfame ion. Additionally, ${ }^{1} \mathrm{H}$ NMR of known complexes $\mathbf{1}$ and $\mathbf{3}$ also provided similar results to the literature (Icbudak et al., 2006; Cavicchioli et al., 2010).

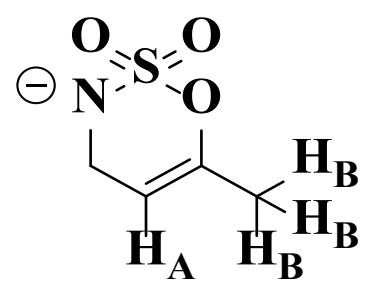

Figure 6. Structure of acesulfame anion.

\section{Mass spectrometry studies}

Mass spectra for novel complexes $\left[\mathrm{Ni}(\text { ace })_{2}\left(\mathrm{PPh}_{3}\right)_{2}\right](4),\left[\mathrm{Cu}(\text { ace })_{2}\left(\mathrm{H}_{2} \mathrm{O}\right)_{2}\right]$ (5) and $\left[\mathrm{Cu}(\text { ace })_{2}\left(\mathrm{PPh}_{3}\right)_{2}\right](6)$ were examined the $\mathrm{m} / \mathrm{z}^{+}$ratio in order to verify the complex formation. $\left[\mathrm{Cu}(\mathrm{ace})_{2}\left(\mathrm{PPh}_{3}\right)_{2}\right](6)$ exhibits the peak at 911.8188 which exactly corresponding to the molecular mass of this substrate. Complex [Ni(ace $\left.)_{2}\left(\mathrm{PPh}_{3}\right)_{2}\right](4)$, the molecular mass of this complex is committed to be 906.09, unfortunately; the peak was presented at 857.1539. The observed signal might be attributed to the leaving of $\mathrm{SO}_{2}$ group in which the result is comparable to the previous report by Yurdakul and Kose (2014). Moreover, complexes 4 and $\mathbf{6}$ also revealed the peaks at 587.2127 and 583.2746 belonged to the metal center bound to two molecules of $\mathrm{PPh}_{3}$ as a minor peak. $\left[\mathrm{Cu}(\text { ace })_{2}\left(\mathrm{H}_{2} \mathrm{O}\right)_{2}\right](5)$ displays $\mathrm{m} / \mathrm{z}^{+}$signal at 525.0061 which is not as same as the suggested molecular structure of the desired product. Therefore, the molecular structure of complex $\mathbf{5}$ is proposed to be dinuclear complex with acesulfame as bridging ligands as the structure shown in Figure 7. 


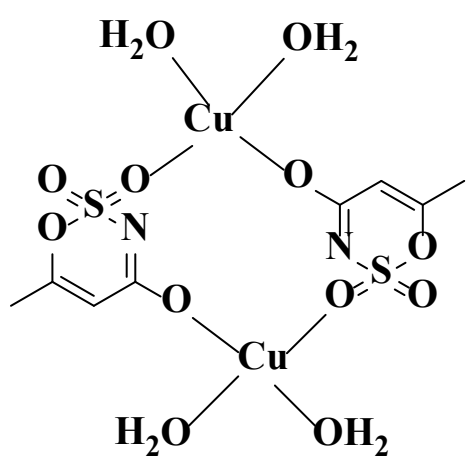

Figure 7. The proposed structure of complex $\left[\mathrm{Cu}(\text { ace })_{2}\left(\mathrm{H}_{2} \mathrm{O}\right)_{2}\right](\mathbf{5})$.

\section{X-Ray powder diffraction studies}

The powder X-ray diffraction studies was carried with $\mathrm{CuK}_{\alpha}(1.54 \AA)$ radiation for $\left[\mathrm{Ni}(\text { ace })_{2}\left(\mathrm{PPh}_{3}\right)_{2}\right](4),\left[\mathrm{Cu}(\text { ace })_{2}\left(\mathrm{H}_{2} \mathrm{O}\right)_{2}\right](5)$ and $\left[\mathrm{Cu}(\text { ace })_{2}\left(\mathrm{PPh}_{3}\right)_{2}\right](\mathbf{6})$ complexes. The $\mathrm{X}$-ray diffraction pattern of the complexes representing in Figure 8, 9 and 10, respectively and d-spacing corelated to $\theta$ are given in Table 3 . The average crystalline sizes of the complexes were calculated using Debye Scherrer equation $(D=K \chi / \beta \cos \theta)(D=$ Particle size, $K=$ Dimensionless shape factor, $\chi=X$-ray wavelength $(0.154 \AA) \beta=$ full width at half maximum of the diffraction peak, $\theta=$ Diffraction angle) (Manjuraj, 2018).

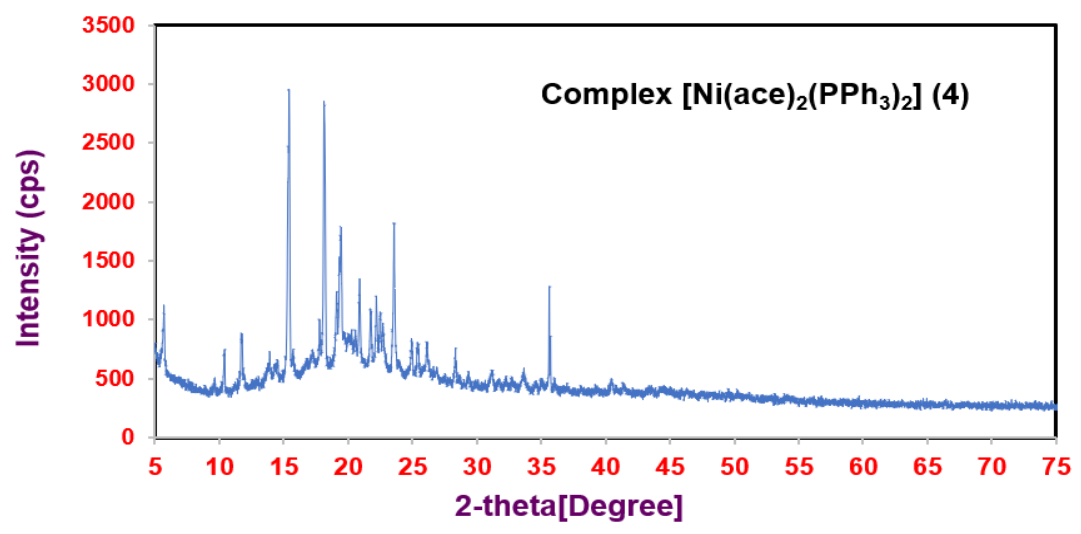

Figure 8. X-ray diffraction patterns of $\left[\mathrm{Ni}(\mathrm{ace})_{2}\left(\mathrm{PPh}_{3}\right)_{2}\right](4)$. 


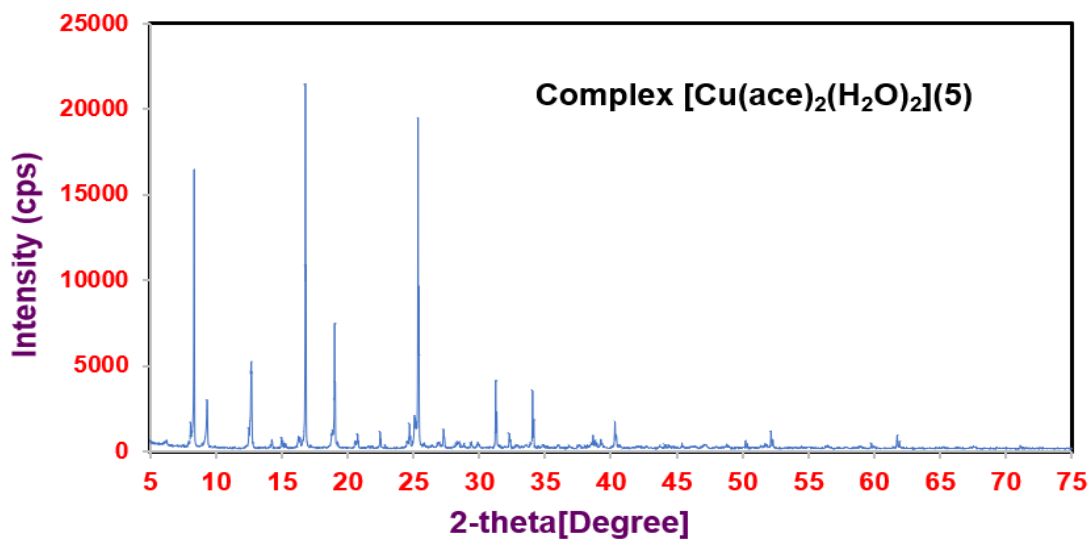

Figure 9. X-ray diffraction patterns of $\left[\mathrm{Cu}(\text { ace })_{2}\left(\mathrm{H}_{2} \mathrm{O}\right)_{2}\right](\mathbf{5})$.

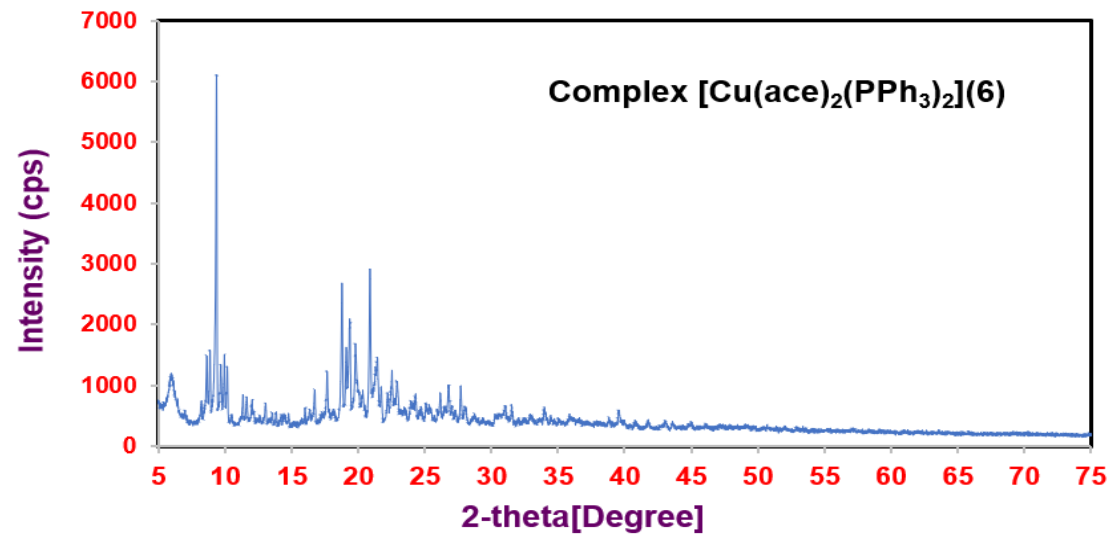

Figure 10. X-ray diffraction patterns of $\left[\mathrm{Cu}(\text { ace })_{2}\left(\mathrm{PPh}_{3}\right)_{2}\right](6)$ 
Table 3. XRD data of complexes 4-6.

\begin{tabular}{cccccccccc}
\hline $\begin{array}{c}\text { Peak } \\
\text { no. }\end{array}$ & \multicolumn{2}{c}{$\left[\mathbf{2 \theta}(\mathbf{a c e})_{\mathbf{2}}\left(\mathbf{P P h}_{3}\right)_{2}\right](\mathbf{4})$} & \multicolumn{2}{c}{$\left[\mathbf{C u}(\mathbf{a c e})_{\mathbf{2}}\left(\mathbf{H}_{\mathbf{2}} \mathbf{O}\right)_{2}\right] \mathbf{( 5 )}$} & \multicolumn{3}{c}{$\left[\mathbf{C u}(\mathbf{a c e})_{\mathbf{2}}\left(\mathbf{P P h}_{3}\right)_{2}\right](\mathbf{6})$} \\
\hline 1 & 5.69 & 0.0496 & 15.513 & 8.36 & 0.0729 & 10.562 & 8.66 & 0.0755 & 10.198 \\
2 & 15.41 & 0.1341 & 5.743 & 12.70 & 0.1106 & 6.962 & 8.90 & 0.0776 & 9.923 \\
3 & 18.12 & 0.1575 & 4.890 & 16.81 & 0.1462 & 5.267 & 9.39 & 0.0819 & 9.402 \\
4 & 19.45 & 0.1689 & 4.558 & 19.03 & 0.1653 & 4.658 & 9.71 & 0.0847 & 9.091 \\
5 & 23.57 & 0.2042 & 3.770 & 25.36 & 0.2195 & 3.508 & 19.37 & 0.1681 & 4.581 \\
6 & 35.62 & 0.3059 & 2.517 & 25.42 & 0.2200 & 3.500 & 20.90 & 0.1814 & 4.245 \\
\hline
\end{tabular}

\section{Anticancer studies}

The prepared complexes were examined in the anticancer activity against A549 lung cancer cells and compared with starting materials and the standard Etoposide. The MTT assay of some examined substrates from this study is presented in Figure 11.
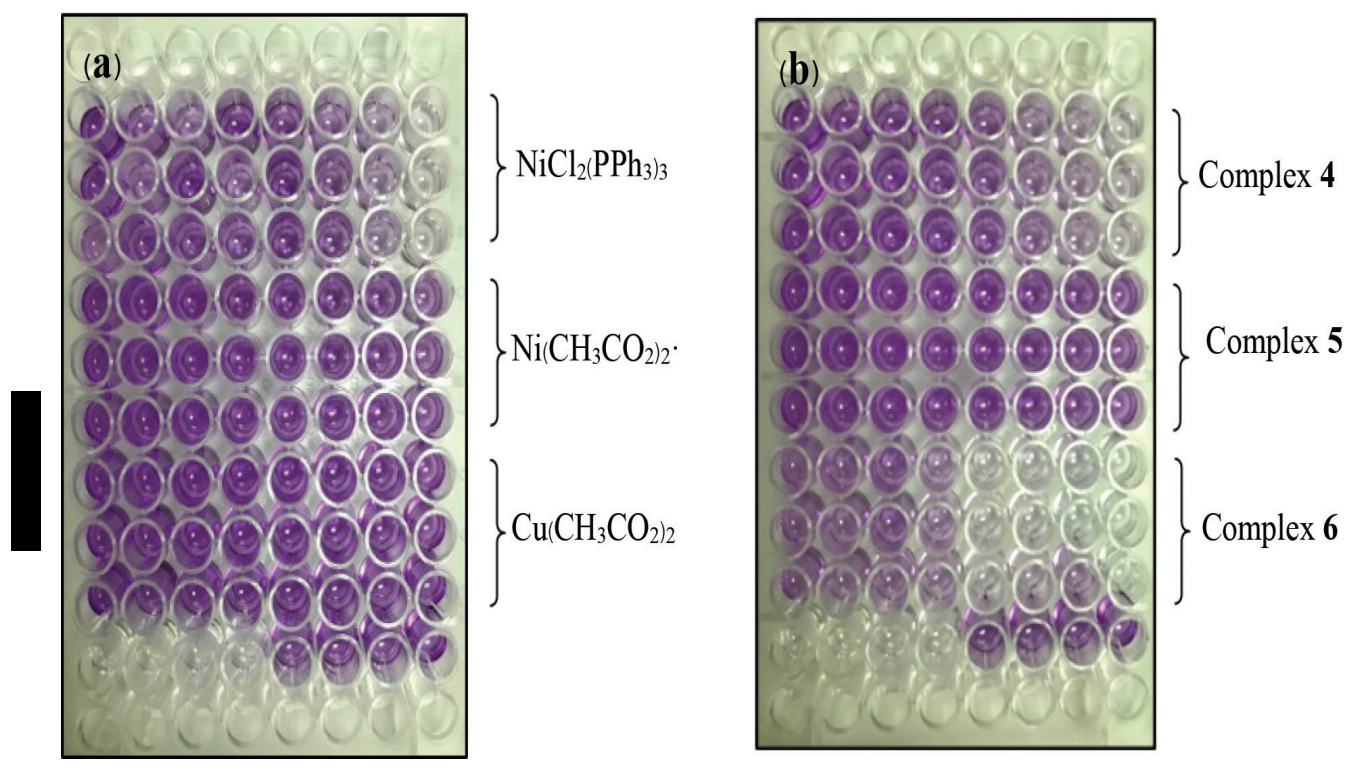

Figure 11. MTT assay of (a) $\mathrm{NiCl}_{2}\left(\mathrm{PPh}_{3}\right)_{3}, \mathrm{Ni}\left(\mathrm{CH}_{3} \mathrm{CO}_{2}\right)_{2} \cdot 6 \mathrm{H}_{2} \mathrm{O}$ and $\mathrm{Cu}\left(\mathrm{CH}_{3} \mathrm{CO}_{2}\right)_{2} \cdot \mathrm{xH}_{2} \mathrm{O}$ (b) complexes 4, 5 and $\mathbf{6}$. 
The $\mathrm{IC}_{50}$ values of complexes $\mathbf{1}, \mathbf{3}$ and $\mathbf{5}$ which contained only acesulfame ligand are 42.04, 50.79 and 222.40, respectively. The results indicate deficient ability of such complexes in comparison to the standard compound, however; these values are still superior than their starting materials. Therefore, this experiment could be confirmed that the synthesized complexes with the introduction of acesulfame performed better activity than non-coordinated compounds and their metal precursors. The excellent results were achieved by complexes with the mixed ligands of acesulfame and triphenylphosphine compounds. Complexes 2, 4 and 6 provided the $\mathrm{IC}_{50}$ values of $1.65,13.45$ and 1.06 , respectively. Amongst the studied metal centers, copper(II) of complex 6 exhibited the best inhibition against the growth of A549 cancer cells. The obtained results are proposed to be involved the influence of metal type and also the proportions of the mixed ligands on the prepared complexes. However, the effect of mixed ligands ratio and structural geometry on biological activity should be further investigated. The results of all biological studies are shown in Table 4.

Table 4. $\mathrm{IC}_{50}$ values of the studied compounds.

\begin{tabular}{lclc}
\hline \multicolumn{1}{c}{ Compounds } & $\mathbf{I C}_{\mathbf{5 0}}(\boldsymbol{\mu M})$ & \multicolumn{1}{c}{ Compounds } & $\mathbf{I C}_{\mathbf{5 0}}(\boldsymbol{\mu M})$ \\
\hline acesulfame & $\mathrm{N} / \mathrm{A}^{*}$ & $\mathrm{PPh}_{3}$ & $\mathrm{~N} / \mathrm{A}$ \\
$\mathrm{AgNO}_{3}$ & $\mathrm{~N} / \mathrm{A}$ & $\mathrm{Ni}\left(\mathrm{CH}_{3} \mathrm{CO}_{2}\right)_{2} \cdot 4 \mathrm{H}_{2} \mathrm{O}$ & 103.70 \\
$\mathrm{NiCl}_{2}\left(\mathrm{PPh}_{3}\right)_{3}$ & 24.95 & $\mathrm{Cu}\left(\mathrm{CH}_{3} \mathrm{CO}_{2}\right)_{2} \cdot \mathrm{xH}_{2} \mathrm{O}$ & 436.70 \\
{$[\mathrm{Ag}(\text { ace })]_{\mathrm{n}} \quad(\mathbf{1})$} & 42.04 & {$\left[\mathrm{Ag}(\mathrm{ace})\left(\mathrm{PPh}_{3}\right)\right](\mathbf{2})$} & 1.65 \\
{$\left[\mathrm{Ni}(\mathrm{ace})_{2}\left(\mathrm{H}_{2} \mathrm{O}\right)_{4}\right](\mathbf{3})$} & 50.79 & {$\left[\mathrm{Ni}(\mathrm{ace})_{2}\left(\mathrm{PPh}_{3}\right)_{2}\right](\mathbf{4})$} & 13.45 \\
{$\left[\mathrm{Cu}(\text { ace })_{2}\left(\mathrm{H}_{2} \mathrm{O}\right)_{2}\right](\mathbf{5})$} & 222.40 & {$\left[\mathrm{Cu}(\mathrm{ace})_{2}\left(\mathrm{PPh}_{3}\right)_{2}\right](\mathbf{6})$} & 1.06 \\
Etoposide & 5.62 & & \\
\hline
\end{tabular}

Note: $*$ The $\mathrm{IC}_{50}$ value cannot be determined.

\section{DISCUSSION}

Analysis of the synthesized complexes 1-6 using spectroscopic methods including X-Ray powder diffraction could verify formation of the desired products. Complex $[\mathrm{Ag}(\text { ace })]_{\mathrm{n}}(\mathbf{1})$ and $\left[\mathrm{Ni}(\text { ace })_{2}\left(\mathrm{H}_{2} \mathrm{O}\right)_{4}\right](\mathbf{3})$ have been already published in their molecular structures and the results from this study are comparable to the previous report. Complex $\left[\mathrm{Ag}(\mathrm{ace})\left(\mathrm{PPh}_{3}\right)\right](2)$ was synthesized established on the literature that using of mixed ligands would increase ability of complexes in the growth inhibition of cancer cells. The previous report by our group revealed the molecular structure obtained from single crystal 
$\mathrm{X}$-ray crystallography which demonstrated the dinuclear complex with trigonal planar structure around silver(I) ion. $\left[\mathrm{Ni}(\text { ace })_{2}\left(\mathrm{PPh}_{3}\right)_{2}\right](\mathbf{4}),\left[\mathrm{Cu}(\text { ace })_{2}\left(\mathrm{H}_{2} \mathrm{O}\right)_{2}\right](5)$ and $\left[\mathrm{Cu}(\mathrm{ace})_{2}\left(\mathrm{PPh}_{3}\right)_{2}\right](6)$ were originally prepared in this research. The results from spectroscopic techniques including X-Ray powder diffraction revealed the formation of theses complexes. $\left[\mathrm{Ni}(\text { ace })_{2}\left(\mathrm{PPh}_{3}\right)_{2}\right](4)$ exhibited the change in its ${ }^{31} \mathrm{P}$ chemical shift up to $25.62 \mathrm{ppm}$ compared to $-5.25 \mathrm{ppm}$ of the free $\mathrm{PPh}_{3}$. Although, the mass spectrum is not corresponding to the proposed structure, the obtained result is still similar to the previous research in which the complex is supposed to lose its $\mathrm{SO}_{2}$ molecule upon the investigation. Copper(II) complex in the presence of only acesulfame ligand (complex 5) revealed the mass spectrum at the peak corelated to the dinuclear structure as presented in Figure 7. IR study exhibits the coordination of water and acesulfame molecules towards the metal center. Additionally, the ${ }^{1} \mathrm{H}$ NMR spectrum also displays the change in chemical shifts of proton at para position of sulfone group and protons of methyl substituent compared to the free acesulfame which could confirm the complex formation. Both spectroscopic studies and mass spectrometry results confirm the formation of complex $\left[\mathrm{Cu}(\text { ace })_{2}\left(\mathrm{PPh}_{3}\right)_{2}\right](6)$ with the structure shown in Figure 4. The X-ray powder diffraction studies showed that $\left.\mathrm{Cu}(\text { ace })_{2}\left(\mathrm{H}_{2} \mathrm{O}\right)_{2}\right](5)$ exhibited sharp peaks indicating high crystallinity of the complex. Based on literature, this may be according to the incorporation of water molecules into the coordination sphere (Khan, 2013). The average crystalline sizes of the complexes calculated using Debye Scherrer equation of $\left[\mathrm{Ni}(\text { ace })_{2}\left(\mathrm{PPh}_{3}\right)_{2}\right](4),\left[\mathrm{Cu}(\mathrm{ace})_{2}\right.$ $\left.\left(\mathrm{H}_{2} \mathrm{O}\right)_{2}\right](5)$ and $\left[\mathrm{Cu}(\text { ace })_{2}\left(\mathrm{PPh}_{3}\right)_{2}\right](6)$ are $34.02,31.50$ and $23.86 \mathrm{~nm}$, respectively suggesting the nanocrystalline phase of all the complexes. (Manjuraj, 2018)

The biological studies display the effect of mixed ligands towards the inhibition of A549 lung cancer cells growing. Starting materials provide high $\mathrm{IC}_{50}$ values which indicate unsatisfactory ability in the interaction with biological substrates and some cannot be even evaluated the $\mathrm{IC}_{50}$ values. The studies demonstrate the importance of coordination compounds in the biological study in which the use of copper(II) complex gave the most excellent capability for killing those cancer cells. The influence of mixed ligand ratio and also geometric structures should be further investigated.

\section{CONCLUSION}

In summary, metal complexes with acesulfame in the absence and in the presence of triphenylphosphine were prepared and characterized. The biological study with cancer cells revealed great activity of the synthesized complexes in comparison to their starting substrates. The capability is increased when 
triphenylphosphine was introduced to the metal complexes. Anyhow, the effect of the proportions of acesulfame and triphenylphosphine including the exact molecular structures of the synthesized complexes should be further investigated.

\section{ACKNOWLEDGEMENTS}

This research was supported by grants funded by Naresuan University. The authors also would like to thank Faculty of Science, Naresuan University and Chiang Mai University for providing instruments.

\section{REFERENCES}

Boonseng, B., Chatwichien, J., Chotima, R., Khudkam, T., and Pila, T. 2018. Synthesis, characterization and anticancer studies of acesulfame mixed with triphenylphosphine silver(I) complexes. Proceedings of the Pure and Applied Chemistry International Conference 2018 (PACCON 2018); 2018 Febuary 7-9; Songkhla: The Chemical Society of Thailand under The Patronage of Professor Dr. HRH Princess Chulabhorn. IN6-IN10. Cavicchioli, M., Massabni, A.C., Heinrich, T.A, Costa-Neto, C.M., Abrao, E.P., Fonseca, B.A.L., Castellano, E.E., Corbi, P.P., Lustri, W.R., and Leite, C.Q.F. 2010. $\mathrm{Pt}(\mathrm{II})$ and $\mathrm{Ag}(\mathrm{I})$ complexes with acesulfame: crystal structure and a study of their antitumoral, antimicrobial and antiviral activities. Journal of Inorganic Biochemistry. 104(5): 533-540. https://doi.org/10.1016/j.jinorgbio.2010.01.004

Chandra, S., and Ruchi. 2013. Synthesis, spectroscopic characterization, molecular modeling and antimicrobial activities of $\mathrm{Mn}(\mathrm{II}), \mathrm{Co}(\mathrm{II}), \mathrm{Ni}(\mathrm{II})$, $\mathrm{Cu}$ (II) complexes containing the tetradentate aza Schiff base ligand. Spectrochimica Acta Part a-Molecular and Biomolecular Spectroscopy. 103: 338-348. https://doi.org/10.1016/j.saa.2012.10.065

Chandra, S., Vandana, and Kumar, S. 2015. Synthesis, spectroscopic, anticancer, antibacterial and antifungal studies of $\mathrm{Ni}$ (II) and $\mathrm{Cu}$ (II) complexes with hydrazine carboxamide, 2-[3-methy1-2-thienyl methylene]. Spectrochimica Acta Part a-Molecular and Biomolecular Spectroscopy. 135: 356-363. https://doi.org/10.1016/j.saa.2014.06.143

Charef, N., Sebti, F., Arrar, L., Djarmouni, M., Boussoualim, N., Baghiani, A., Khennouf, S., Ourari, A., AlDamen, M.A., Mubarak, M.S., et al. 2015. Synthesis, characterization, X-ray structures, and biological activity of some metal complexes of the Schiff base 2,2 '-(((azanediylbis (propane-3,1-diyl))bis(azanylylidene))bis(methanylylidene))diphenol. Polyhedron. 85: 450-456. https://doi.org/10.1016/j.poly.2014.09.006 
Cong, W.N., Wang, R., Cai, H., Daimon, C.M., Scheibye-Knudsen, M., Bohr, V.A., Turkin, R., Wood, W.H., Becker, K.G., Moaddel, R., et al. 2013. Long-term artificial sweetener acesulfame potassium treatment alters neurometabolic functions in C57BL/6J mice. Plos One. 8(8): 1-18. https://doi.org/10.1371/journal.pone.0070257

Gazdar, A.F., Girard, L., Lockwood, W.W., Lam, W.L., and Minna, J.D. 2010. Lung cancer cell lines as tools for biomedical discovery and research. Jnci-Journal of the National Cancer Institute. 102(17): 1310-1321. https://doi.org/10.1093/jnci/djq279

Ghobadi, K., Zare, H.R., Khoshro, H., Gorji, A., and Benvidi, A. 2018. Effect of molecular structure of the N, N'-bis(2-hydroxy-1-naphthaldehyde)-1,3-phenylenediimine ligand on the electrocatalytic properties of its $\mathrm{Ni}(\mathrm{II})$ complex for reduction of $\mathrm{CO}_{2}$. Journal of Molecular Structure. 1171: 466-470. https://doi.org/10.1016/j.molstruc.2018.06.023

Icbudak, H., Adiyaman, E., Cetin, N., Bulut, A., and Buyukgungor, O. 2006. Synthesis, structural characterization and chromotropism of a $\mathrm{Ni}(\mathrm{II})$ and a Co(II) compound with acesulfamate as a ligand. Transition Metal Chemistry. 31(5): 666-672. https://doi.org/10.1007/s11243-006-0045-x

Kaplan, A., Ciftci, G.A., and Kutlu, H.M. 2017. The apoptotic and genomic studies on A549 cell line induced by silver nitrate. Tumor Biology. 39(4): 1-12. https://doi.org/10.1177/1010428317695033

Khan, M.I., Khan, A., Hussain, I., Khan, M.A., Gul, S., Iqbal, M., Rahman, I.U., and Khuda, F. 2013. Spectral, XRD, SEM and biological properties of new mononuclear Schiff base transition metal complexes. Inorganic Chemistry Communications. 35: 104-109. https://doi.org/ 10.1016/j.inoche.2013.06.014

Kumar, G., Kumar, D., Devi, S., Johari, R., and Singh, C.P. 2010. Synthesis, spectral characterization and antimicrobial evaluation of Schiff base $\mathrm{Cu}$ (II), Ni (II) and Co (II) complexes. European Journal of Medicinal Chemistry. 45(7): 3056-3062. https://doi.org/10.1016/j.ejmech.2010.03. 036

Manjuraj, T., Krishnamurthy, G., Bodke, Y.D., Naik, H.S.B., and Kumar, H.S.A. 2018. Synthesis, XRD, thermal, spectroscopic studies and biologicalevaluation of $\mathrm{Co}(\mathrm{II}), \mathrm{Ni}(\mathrm{II}) \mathrm{Cu}(\mathrm{II})$ metal complexes derived from 2-benzimidazole. Journal of Molecular Structure. 1171: 481-487. https:// doi.org/10.1016/j.molstruc.2018.06.055

Mo, Q.Y., Deng, J.G., Liu, Y.N., Huang, G.D., Li, Z.W., Yu, P., Gou, Y., and Yang, F. 2018. Mixed-ligand $\mathrm{Cu}(\mathrm{II})$ hydrazone complexes designed to enhance anticancer activity. European Journal of Medicinal Chemistry. 156: 368-380. https://doi.org/10.1016/j.ejmech.2018.07.022 
Nawaz, S., Isab, A.A., Merz, K., Vasylyeva, V., Metzler-Nolte, N., Saleem, M., and Ahmad, S. 2011. Synthesis, characterization and antimicrobial studies of mixed ligand silver(I) complexes of triphenylphosphine and heterocyclic thiones: crystal structure of bis[ $\{(\mathrm{mu}(2)$-diazinane-2thione) (diazinane-2-thione) (triphenylphosphine)silver(I) nitrate\}]. Polyhedron. 30(9): 1502-1506. https://doi.org/10.1016/j.poly.2011.02. 054

Saha, D., Gayen, S., and Koner, S. 2018. $\mathrm{Cu}(\mathrm{II}) / \mathrm{Cu}(\mathrm{II})-\mathrm{Mg}$ (II) containing pyridine-2,5-dicarboxylate frameworks: Synthesis, structural diversity, inter-conversion and heterogeneous catalytic epoxidation. Polyhedron. 146: 93-98. https://doi.org/10.1016/j.poly.2018.02.023

Yurdakul, Ö., and Köse, D.A. 2014. Mixed ligand complexes of acesulfame/ nicotinamide with earth alkaline metal cations $\mathrm{Mg}^{\mathrm{II}}, \mathrm{Ca}^{\mathrm{II}}, \mathrm{Ba}^{\mathrm{II}}$ and $\mathrm{Sr}^{\mathrm{II}}$ : synthesis and characterization, Hittite Journal of Science and Engineering. 1(1): 51-57. https://doi.org/10.17350/HJSE19030000008 